\title{
PESTS PATHOGENS AND POVERTY: BIOLOGICAL INVASIONS AND AGRICULTURAL DEPENDENCE
}

\author{
Charles Perrings \\ Global Institute of Sustainability \\ Arizona State University \\ Box 873211, \\ Tempe, \\ AZ 85287-3211, \\ USA \\ e-mail: Charles.Perrings@asu.edu
}

January 2006

\section{Introduction}

The problem addressed in this paper is the linkage between poverty and invasive alien species (IAS) - the introduction, establishment and spread of species outside of their original range. There are two main dimensions to the problem. One is the connection between poverty and the likelihood of the introduction, establishment or spread of invasive species. It includes the relation between poverty and strategies for the management of invasive species, investment in invasive species detection and control, and collaboration in international control measures. The second is the connection between poverty and the costs or benefits of invasions. This includes the links between invasive species, the structure of the economy, and poverty. It covers the relation between poverty and dependence on agriculture, wildlife utilisation, forestry and fisheries, and the importance of the common property.

These two dimensions have been addressed in three generally distinct literatures. One is the literature on the costs of biological invasions. It is closely associated with the work of David Pimentel and colleagues, and comprises estimates of the more direct costs of invasive pests and pathogens in selected countries, including at least some developing countries (South Africa, India and Brazil). It also includes a longer standing literature on the costs of various animal and plant pests and pathogens in agriculture, forestry and - to a lesser extent - in fisheries. A second is on economics of invasive species. The research undertaken as part of GISP I was the first inquiry into this problem (Perrings et al, 2000). Since then a new literature on the economics of biological invasions has developed which looks at the efficient management of invasive species. As yet, this literature has not considered equity issues or the link between biological invasions and poverty, but it does the address the factors that influence the probability of the introduction and spread of invasive species and the effectiveness of control. These can be related to poverty. A third literature considers the link between other kinds of environmental change and poverty, and includes both 
theoretical and empirical studies. It has tended to focus on particular areas of environmental change - especially pollution (air and water), habitat conversion (deforestation), water issues (water quality and water supply), and disease. However, this too can be used to say much about the link between the environmental changes associated with invasive species and poverty.

The paper begins with the last of these - the general evidence for an empirical relation between poverty and environmental change, and between poverty and the primary source of IAS worldwide - the growth of trade, transport and travel. There are, by now, a number of surveys of the economics of biological invasions. Lovell and Stone (2005) have aquatic invasive species, while Evans (2003), Eisworth and Johnson (2004) consider the literature on terrestrial systems - the latter in the context of a paper developing a general model for the management of invasive species. Stuztman et al (2004) offer an annotated bibliography of economics of invasive plants.

There are three major points at issue in the economics of invasive species. The first is that the introduction, establishment and spread of potentially harmful alien species constitute an externality of international markets (international trade). In the absence of complete markets, the risk of biological invasions increases with the growth of trade. The second is that the control of invasive species is a public good at several different levels - national, regional and global. The provision of the public good requires the development of institutions that operate at the appropriate level, and that can solve the free-rider problem at that level. This involves application of the subsidiarity principle to the development of governance mechanisms and international agreements. The third point at issue is the appropriate specification of the management problem, and the evaluation of control options (where control subsumes interception, quarantine, eradication, containment and other management options).

The economics of the problem involve the identification of the source of the externality, estimation of its consequences for the welfare of people affected, and the development of mechanisms to ensure that commensurate resources committed to detection and control are commensurate. The methodological question is the following: given the set of prices, regulations, property rights and institutional conditions, how should the management problem be formulated and solved? It involves the identification and management of the risks and uncertainties associated with the introduction of novel species. It also involves the treatment of irreversible changes. When is it optimal to mitigate the risks of invasions (to take action that reduces the probability of an invasions occurring), and when is it optimal to adapt (to take action that reduces the costs of invasions without affecting the probability that they will occur)(Perrings, 2005)? Evans et al (2002) argue that economics has two major contributions to make to research on IAS. The first is to provide estimates of the impacts of invasions, to improve both cost effectiveness and efficiency of publicly funded IAS control programs. The second is to develop economic sanitary and phytosanitary measures. This paper addresses both questions.

The paper is organised in 6 sections. Section 2 considers the general relationship between invasive species and poverty. Section 3 then evaluates the relation between trade and invasive species. That is followed by three sections on the evaluation of 
damage costs of IAS, the development of economic instruments to internalise IAS externalities, and expenditures on IAS control as a public good in poor economies and poor regions. A final section considers the decision-tools available to inform mitigation and adaptation strategies, and relates these to the problem of uncertainty.

\section{Poverty and Environmental Change}

The linkages between poverty and environmental change have been widely studied, but it would be wrong to say that they are well understood. The Brundtland Report (WCED, 1987) argued that there existed a causal connection between environmental change and poverty both within and between generations. A large literature has subsequently examined the empirical relation between per capita income (GDP or GNP) and environmental change. The 'Environmental Kuznets Curve' literature stemmed from Grossman and Krueger's (1995) assessment of the environmental implications of Mexico's inclusion in the North American Free Trade Area (NAFTA), which showed that certain indicators of environmental quality first deteriorate and then improve as per capita incomes rise.

The relation between per capita income and various other indicators of environmental change have subsequently been studied, using a range of data bases and econometric approaches (see Stern 1998a, 1998b and 2004 for reviews of this literature). An inverted ' $U$ ' shaped curve was found for the relation between per capita income and various atmospheric pollutants using both cross-sectional and panel data (Shafik, 1994; Seldon and Song, 1994; Cole et al, 1997; Stern and Common, 2001), but the relation is by no means consistent. For some measures of environmental quality the relation with per capita income has been found to be monotonically increasing (e.g. carbon dioxide or municipal waste) or decreasing (eg faecal coliform in drinking water). For others it has been found to have more than one turning point. Moreover, even where the best fit is given by a quadratic function - the inverted ' $U$ ' - there are wide discrepancies in estimations of the turning point. This is the level of per capita income at which the particular measure of environmental quality starts to improve as per capita incomes rise. While some have chosen to interpret the Environmental Kuznets Curve as evidence that economic growth will, in some sense, take care of the environment, the consensus view is that there are no general rules to be drawn (Ekborn and Bojo, 1999; Markandya, 2000, 2001). The relation between changes in income and changes in the environment are complex, involving feedback effects in both directions.

Markandya's (2001) review of the literature on the relation between poverty, environmental change and sustainable development suggested that to the question, 'does poverty damage the environment?' the answer was broadly 'no'. To the question 'does environmental degradation hurt the poor?' the answer was broadly 'yes'. Hence he concluded while poverty alleviation would not necessarily enhance environmental quality, and may in fact increase stress on the environment, environmental protection would generally benefit the poor. Of course there are many caveats to this conclusion. Cutting the poor off from access to environmental resources by the establishment of protected areas without paying compensation is unlikely to improve their well-being. 
The ambiguous nature of the statistical results on the linkages between poverty and the environment is reflected in the various case studies of environmental resource use in poor countries. For reasons that are well understood, the scarcity of commodities that satisfy basic needs such as water and fuelwood affect the poor more than the rich (Kumar and Hotchkiss, 1988). So it is not at all surprising that environmental change the reduces the supply of basic goods held in common property should impact the poor. Where the case studies are less consistent is in the analysis of the relation between poverty, population growth, environmental change and institutions.

There are numerous studies of the effect of population growth - whether due to migration or fertility - on deforestation. Lopez and Scoeria (1996) found that inmigration to Belize from other Central American countries accounted for around a third of deforestation in that country. Population growth has similarly been implicated in environmental change in many other cases (De Janvry and Garcia, 1988; Cleaver and Schreiber, 1994; Lopez, 1992; Lopez and Scoeria, 1996). Sub-Saharan Africa has, however, provided some well known counter examples, where productivity increases that have accompanied population growth have more than compensated for any reduction in environmental resources (Pingali et al, 1987; Tiffen et al, 1994). Heath and Binswanger (1996), using the cases of Kenya and Ethiopia, argued that whether or not population growth had adverse effects on the environment depended on institutional conditions. There is also some evidence that the linkage between poverty, demography and environmental change is influenced by changes in household composition. Linde-Rahr's (2002) study of afforestation in Vietnam, for example, showed that in households with larger numbers of female members, tree planting was positively correlated with income, but that in households with larger numbers of male members the opposite was true.

What the differences between the various case studies has shown is that it is the determinants of household decisions on the use of environmental resources that matters. On the links between population growth and environmental change, Dasgupta's (1993, 2001) investigation of the connection between poverty, fertility decisions and environmental change concluded that both fertility decisions and the use made of environmental resources are strongly influenced by household's longterm security of income. Where poverty includes low expectations of secure future income, household responses include high fertility rates leading to increased pressure on the environment. This is especially marked where access to environmental resources is unregulated. Since this in turn increases uncertainty about future income, there is a positive feedback between poverty, fertility decisions, and environmental degradation.

Another strand of the literature has addressed the link between poverty and the rate at which households discount the future (e.g. Perrings, 1989; Chavas, 2004). Building on the long-held observation that discount rates are not independent of income (Fisher 1930), these studies treat discount rates as endogenous. They find that if poverty causes people to ignore the longer-term consequences of their decisions, it also affects investment in conservation and environmental enhancement. Chavas's important (2004) paper shows that if the discount rate is endogenous, and decreases in income, then in contrast to Markandya's view, poverty can contribute to environmental degradation. This is certainly consistent with at least some empirical findings on the 
topic (e.g. Pender, 1996; Holden, Shiferaw and Wik, 1998), although, as Markandya points out, the evidence remains mixed.

The linkage between poverty and growth has also been examined at a macroeconomic level, where the evidence in the 1990s showed that declining public expenditures and a worsening distribution of income affected the ability of the poor to invest. In many cases, the rural poor were unable to respond to changing incentives while reductions in extension services and marketing support have further depressed rural incomes, particularly affecting rural women (Birdsall and Londano, 1997; Reed, 1996). What made these findings disturbing was that many indicators of economic performance, including measures of trade growth, were moving in the opposite direction.

Table 1 shows that there has been substantial growth in capital flows and foreign direct investment in the last decade in all income groups and all regions. However, it both capital flows and FDI are much lower in areas where poverty is most persistent. This has implications for the resources committed to maintaining ecosystem services, and the environmental assets from which such services are derived. The best current measure of this is the World Bank's adjusted net savings rate, which modifies conventional measures of net national savings by including changes not only in produced capital, but also in human and natural or environmental capital. Adjusted net savings were originally defined as genuine savings (Hamilton and Clemens, 1999; Hamilton, 2000), or genuine investment (Dasgupta, 2001; Arrow et al, 2003). It is a measure of the change in a country's wealth.

Table 1: Integration in the world economy

\begin{tabular}{|c|c|c|c|c|c|c|}
\hline & \multicolumn{2}{|c|}{$\begin{array}{l}\text { Trade in goods } \\
\text { \% GDP }\end{array}$} & \multicolumn{4}{|c|}{$\begin{array}{l}\text { Gross private capitalGross foreign direct } \\
\text { flows } \\
\text { \% GDP } \\
\text { investment } \\
\text { \% GDP } \\
\end{array}$} \\
\hline & 1990 & 2003 & 1990 & 2003 & 1990 & 2003 \\
\hline World & $32.5 \mathrm{w}$ & $41.5 \mathrm{w}$ & $10.3 w$ & $24.2 \mathrm{w}$ & $2.7 \mathrm{w}$ & $4.9 w$ \\
\hline Low income & 24.6 & 34.9 & 2.8 & 4.6 & 0.4 & 1.5 \\
\hline Middle income & 35.5 & 58.3 & 6.7 & 13.2 & 1 & 3.4 \\
\hline Low \& middle income & 33.6 & 54.7 & 6 & 12.8 & 0.9 & 3.3 \\
\hline East Asia \& Pacific & 47 & 70.5 & 5 & 14.4 & 1.7 & 3.9 \\
\hline Europe \& Central Asia & .. & 66.7 & .. & 16.5 & .. & 4.4 \\
\hline Latin America \& Carib. & 23.2 & 42.2 & 8 & 9.9 & 0.9 & 2.8 \\
\hline Middle East \& N. Africa & 46.6 & 50.4 & 6 & 12.6 & 0.8 & 1.3 \\
\hline South Asia & 16.5 & 24.1 & 1.4 & 3.4 & 0.1 & 0.8 \\
\hline Sub-Saharan Africa & 42.4 & 52.7 & 5.1 & 6.7 & 1 & 1.9 \\
\hline High income & 32.3 & 38.3 & 11.1 & 26.6 & 3 & 5.2 \\
\hline
\end{tabular}

Source: World Bank. 2005. Global Economic Prospects, World Bank, Washington D.C.

Estimates of adjusted net savings are generally lower than other savings measures, reflecting the depreciation or degradation of environmental assets. Moreover, once population growth is taken into account many regions of the world experienced negative changes in wealth per head during the last three decades of the $20^{\text {th }}$ century (Table 2).

Even regions that recorded strongly positive growth in conventional measures of economic performance, like India, recorded declining per capita inclusive wealth. In some regions the fall in the value of per capita wealth was very substantial. In sub- 
Saharan Africa, for example, annual per capita changes in wealth averaged $-3.4 \%$ between 1965 and 1996. In other words, Africans lost almost half of their wealth in that period (Dasgupta, 2001).

Table 2: Changes in inclusive wealth in China, India and sub-Saharan Africa, 1965-1996

\begin{tabular}{llllll}
\hline & $\% \Delta \mathrm{N}$ & $\% \Delta \mathrm{Y} / \mathrm{N}$ & $\% \Delta \mathrm{HDI}$ & $(\mathrm{dV} / \mathrm{dt}) / \mathrm{Y}$ & $\% \Delta \mathrm{V} / \mathrm{N}$ \\
\hline & 1 & 2 & 3 & 4 & 5 \\
China & 1 & 2 & 3 & 4 & 5 \\
India & 1.7 & 6.7 & -0.2 & 0.100 & 0.8 \\
Sub-Saharan Africa & 2.1 & 2.3 & 2.2 & 0.08 & -0.1 \\
\hline
\end{tabular}

Column 1: Average annual percentage rate of population growth, 1965-1996

Column 2: Average annual percentage rate change in per capita GNP, 1965-1996

Column 3: Average annual percentage rate of change in HDI, 1987-1997

Column 4: Genuine investment as a proportion of GDP, 1970-1993

Column 5: Average annual percentage rate of per capita wealth, 1970-1993

Source: Adapted from Dasupta (2001)

Since the turn of the century the position has improved for many regions. In 2003 adjusted net savings were positive for all regions other than the Middle East (Table 3). However, they were close to zero in Sub Saharan Africa as a whole, and were strongly negative in a number of countries. ${ }^{1}$ In per capita terms, therefore, Africans were still getting poorer once changes in environmental stocks were taken into account.

Table 3: Depletion of natural capital, 2003

\begin{tabular}{llll}
\hline & $\begin{array}{l}\text { Gross national } \\
\text { savings \% GNI }\end{array}$ & $\begin{array}{l}\text { Net national savings } \\
\text { \% GNI }\end{array}$ & $\begin{array}{l}\text { Adjusted net } \\
\text { savings \% GNI }\end{array}$ \\
\hline World & $20.8 \mathrm{w}$ & $8.2 \mathrm{w}$ & $9.4 \mathrm{w}$ \\
Low income & 23.1 & 14.2 & 8.7 \\
Middle income & 27.9 & 17.8 & 10.1 \\
Low \& middle income & 27.2 & 17.3 & 10 \\
East Asia \& Pacific & 41.8 & 32.6 & 28.1 \\
Europe \& Central Asia & 21.9 & 11.2 & 1.5 \\
Latin America \& Caribbean & 19.5 & 9.2 & 5.3 \\
Middle East \& N. Africa & 31.2 & 21.3 & -6.2 \\
South Asia & 24.9 & 15.9 & 13.8 \\
Sub-Saharan Africa & 16.9 & 6.3 & 0.7 \\
High income & 19.3 & 6.1 & 9.3 \\
Europe EMU & 21.3 & 7.5 & 11.6 \\
\hline
\end{tabular}

Source: World Bank. 2005. Global Economic Prospects, World Bank, Washington D.C.

Case studies of changes in inclusive wealth in particular countries have identified the policies and investment strategies that explain changes in national wealth. For example, Lange (2004) cites the contrasting cases of Botswana and Namibia. After independence in 1996 Botswana chose to reinvest the rents from the mining sector in building its capital stock. Namibia did not. The result is that whereas Botswana has tripled per capita wealth in the last three decades of the $20^{\text {th }}$ century, Namibia's per

\footnotetext{
${ }^{1}$ In the Middle East adjusted net savings reflect the depletion of oil stocks. In Sub-Saharan Africa, the worst performing countries are also oil-producing states (Nigeria, -31.4; Angola -28.5; Congo, -26.3) that are not reinvesting oil rents. Gelb and Hamilton (2004) show that using current methods for constructing adjusted net savings, they are negatively correlated with dependence on both mineral and energy wealth.
} 
capita wealth has declined. In the 1980s Namibia's per capita wealth was $75 \%$ greater than Botswana's. By the end of the 1990s it was only 33\% of Botswana's.

Changes in inclusive wealth are reflected in both recorded and projected poverty levels. Table 4 describes current expectations about the growth in the number of people in poverty over the next ten years. Using the number of people living on less than either \$1 or \$2 per day as the criterion, it shows poverty increasing in a number of developing regions in the last decade of the $20^{\text {th }}$ century, but projects that it will either recover or fall in all regions except Sub-Saharan Africa in the next ten years.

Table 4: Number of people in poverty

Number of people in poverty (millions living on less than \$1 or \$2 per day)

\begin{tabular}{lllllll}
\hline & \multicolumn{3}{l}{ \$1 per day } & \multicolumn{4}{l}{ \$2 per day } \\
Region & 1990 & 2000 & 2015 & 1990 & 2001 & 2015 \\
East Asia and Pacific & 470 & 261 & 44 & 1116 & 864 & 230 \\
$\quad$ China & 361 & 204 & 41 & 825 & 594 & 134 \\
$\quad$ Rest of East Asia and Pacific & 110 & 57 & 3 & 292 & 271 & 95 \\
Europe and Central Asia & 6 & 20 & 6 & 23 & 93 & 25 \\
Latin America and the Caribbean & 48 & 56 & 46 & 125 & 128 & 122 \\
Middle East and North Africa & 5 & 8 & 4 & 51 & 70 & 46 \\
South Asia & 467 & 432 & 268 & 958 & 1064 & 912 \\
Sub-Saharan Africa & 241 & 323 & 366 & 382 & 516 & 612 \\
Total & 1237 & 1100 & 734 & 2654 & 2735 & 1946 \\
$\quad$ Excluding China & 877 & 896 & 692 & 1829 & 2142 & 1812 \\
\hline
\end{tabular}

Source: World Bank. 2005. Global Economic Prospects, World Bank, Washington D.C.

The persistence of poverty in regions such as Sub-Saharan Africa is also reflected in changes in the rural population (Table 5). The linkage between poverty and rural activities has been well documented (Jazairy et al, 1992).

Table 5: Rural population

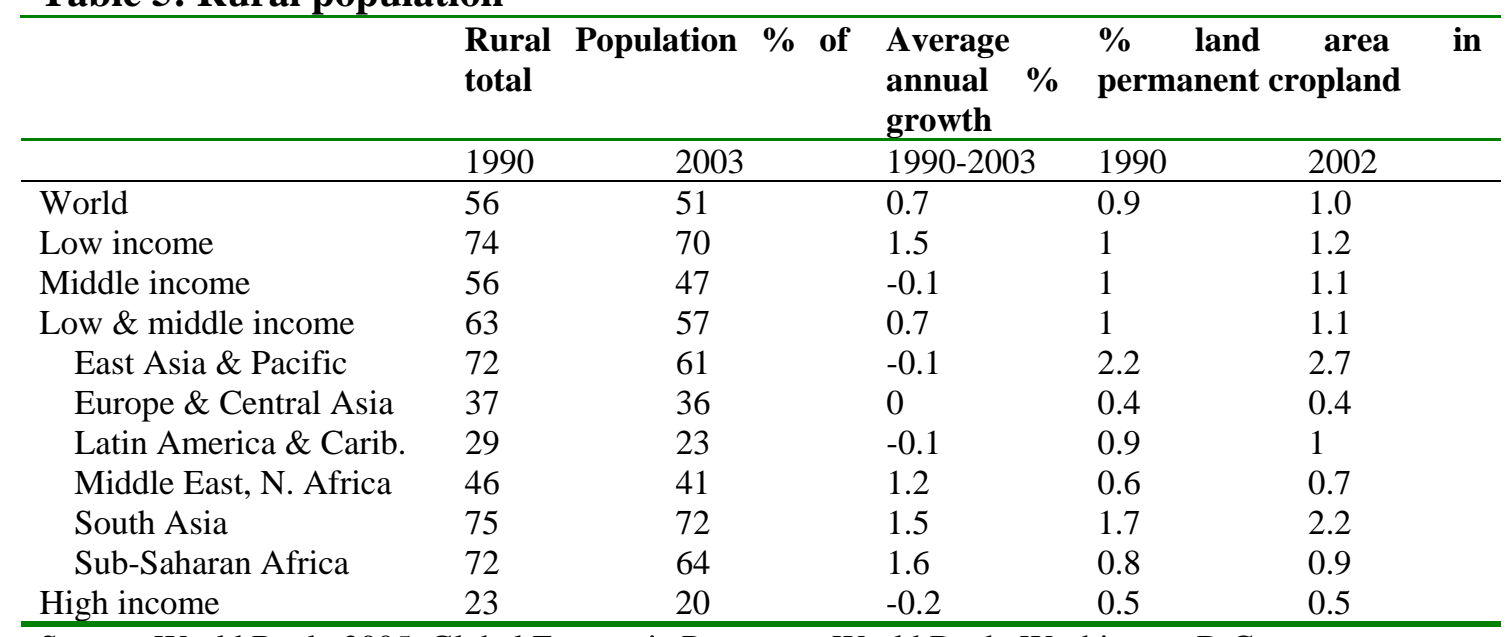

Source: World Bank. 2005. Global Economic Prospects, World Bank, Washington D.C.

Although the proportion of the population in rural areas has declined in every region due to the continuing movement of people from rural to urban areas, rural population growth remains positive in many low-income regions. It is highest in South Asia and Sub-Saharan Africa, in both of which agricultural and forest-based employment account for a higher proportion of the labour force than elsewhere. 
What does this mean for the linkages between poverty and biological invasions? There are three important points to make, each of which is considered later. First, if the resources committed to border inspection are positively correlated with GDP, the growth of trade increases the invasion risks of poor countries and poor regions disproportionately. That is, the risks of undetected species introductions will be higher. Second, if investment in the conservation of ecosystem services and the control of invasive species are also positively correlated with GDP, poor countries and poor regions may also be more invasible than rich countries and regions. That is, the risk that introduced species will be able to establish and spread will be higher in poor regions. Third, since invasive pests and pathogens primarily affect agriculture, forestry and fisheries, the greater dependence of poor producers on primary production makes them more vulnerable to the effects of biological invasions. In other words, the cost of invasive species will tend to impact more people in poor, resource dependent economies than in rich economies, and will more directly affect their livelihoods.

\section{Trade and invasive species}

From an ecological perspective, any species introduced to an ecosystem beyond its 'home' range that establishes, naturalises and spreads is said to be invasive (Williamson, 1996). From a policy perspective, however, the focus is generally on species whose home range lies beyond the national jurisdiction. In other words, the alien species that attract attention are those that are introduced as a consequence of international trade, transport or travel. This includes both species that are deliberately introduced as domesticated plants or animals, and those that are introduced as an unintended by-product of the import of other goods and services - the so-called 'hitchhiker' species. The OTA (1993) estimated that four out of five invasive terrestrial weeds in the US that had appeared during the $20^{\text {th }}$ century were introduced as by-products of the commodity trade. Although data are lacking on aquatic species, the proportion of invasive aquatic species that have been introduced by shipping is likely to be much higher. Many of the most famous examples of damaging species introductions, e.g. Zebra Mussel (Dreissena polymorpha) and the Asian Clam (Corbicula fluminea), are associated with ballast water exchange in ships. Their appearance is evidence of the failure of both international and domestic markets (Perrings et al, 2002; Margolis, Shogren and Fischer, 2005).

The precise relation between the growth in trade and invasive species is still unknown, reflecting the paucity of time series on species introductions to match the available time series on trade. Dalmazzone (2000) showed that economies that are more open tend to be more vulnerable to invasions. Small island states in particular are often geared to the production of primary products for export, and are more dependent on imports than continental countries. ${ }^{2}$ Since they are also ecologically more vulnerable to invasions than continental ecosystems, it follows that trade is not the only explanation for the success of introduced species in such economies. More recently, Levine and D'Antonio (2003) have considered merchandise trade as a predictor of invasions focusing of insects, plant pathogens and molluscs. They have

\footnotetext{
${ }^{2}$ For example, the average percentage of merchandise imports as a share of the GDP, in the sample considered in Dalmazzone (2000), is 43 percent for island countries, against an average 32 percent for the whole sample, and 26.8 percent for continental countries.
} 
also used the resulting model to predict increases in invasions over the next two decades. They conclude that trade-induced invasions will increase by between 3 and 61 percent, depending on the model and the species.

What is beyond dispute is that species introductions increase with the volume of trade, and that the frequency with which a species is introduced is positively correlated with the probability that it will establish (Enserink, 1999). This means that the growth of trade, other things being equal, will increase the risk both of new introductions and of the establishment of introduced species (Lockwood et al, 2005).

Of course other things are not equal. What matters more to the ability to predict invasion risks than simply the volume of trade are the bioclimatic similarities between the ecosystems being connected, the nature of the pathways (e.g. the time introduced species are in transit and their conditions during transit), the nature of the species themselves (e.g. traits, such as high plasticity, that make species invasive), and the invasibility of the ecosystems into which species are being introduced (e.g. the effects of fragmentation and biodiversity loss). However, given these conditions, an increase in propagule pressure due to an increase in the trade of goods will increase the risk of biological invasions. Furthermore, an increase in trade is expected to lead to habitat loss through conversion of land for agriculture, forestry and industry, with negative implications for biodiversity and the invisibility of ecosystems (Polasky et al, 2004). It follows that to understand the implications for biological invasions of changes in trade it is necessary to understand how the pattern of trade is changing as the volume of trade grows.

For the countries and regions where the world's poor live the trade that matters is trade in the products of agriculture forestry and fisheries. Recent analyses of changes in the pattern of world commodity trade have point up a number of important features of agricultural trade. The first is that while the share of agriculture in global trade has been falling, it remains especially important to people in poverty precisely because poor people tend to live in rural areas, and to derive their income from agriculture. The ratio of farm to non-farm income ranges from 40 to 80 per cent in low-income countries, but is only around 1 per cent in high-income countries. The fact that the decline in agricultural prices affects developing countries more than developed countries - world raw commodity prices declined by 6.6 per cent in the period 19902000, but developing country raw commodity prices declined by 15.2 per cent - also has implications for the rural poor (Aksoy, 2005).

Aside from trade, transfers are also especially important in poorer regions. For example, grey leaf spot was first reported in South Africa in 1988 (Ward, 1996). It has subsequently spread northwards into all the main maize-growing areas of Africa, and its affect on yields has been such that it is now argued to pose a serious threat to food security (Rangi, 2004). It was thought to have been introduced to the continent in Grey leaf spot is thought to have been introduced into Africa in US food aid shipments of maize in during the drought years of the 1980's (Ward et al., 1999). Another example is parthenium weed from Mexico. This was first detected in Ethiopia in 1988 near food-aid distribution centres implying that it had accompanied wheat grain distributed as food aid during the drought (GISP, 2004). Since lower sanitary and phytosanitary standards apply to food aid, particularly emergency food 
aid, it may not be so surprising that the introduction and spread of potentially invasive species would follow the distribution of emergency relief.

A second important feature of agricultural trade in developing countries is that although it continued to grow at around 3.4 per cent in the 1990s, almost all the growth was accounted for by trade with other developing countries (Table 6). More than 50 per cent of food imports in developing countries derives from other developing countries (Aksoy, 2005). The World Bank reports that a major trend in the trading system involves the proliferation of bilateral and regional trade agreements (RTAs), and especially the proliferation of South-South RTAs (World Bank, 2005). The number of RTAs has increased fourfold since 1990 and currently stands at over 230. Indeed, RTAs now account for nearly 40 percent of world trade.

Table 6: Global Agricultural Trade Flows (US\$ billion)

\begin{tabular}{llllllllll}
\hline & & $\begin{array}{l}\text { Low } \\
\text { income } \\
\text { countries }\end{array}$ & $\begin{array}{l}\text { Middle } \\
\text { income } \\
\text { countries }\end{array}$ & $\begin{array}{l}\text { Develop- } \\
\text { ing } \\
\text { countries }\end{array}$ & EU-15 & Japan & NAFTA & $\begin{array}{l}\text { Other } \\
\text { industrial } \\
\text { countries }\end{array}$ & $\begin{array}{l}\text { Total } \\
\text { imports }\end{array}$ \\
\hline Low- & $1980 / 1$ & 0.86 & 2.16 & 3.03 & 2.19 & 0.20 & 1.42 & 0.63 & 7.47 \\
income & $1990 / 1$ & 0.81 & 2.52 & 3.33 & 1.17 & 0.06 & 1.22 & 0.73 & 6.52 \\
countries & $2000 / 1$ & 1.50 & 4.48 & 5.98 & 2.01 & 0.06 & 1.99 & 1.78 & 11.82 \\
Middle- & $1980 / 1$ & 3.05 & 25.73 & 28.78 & 14.55 & 1.02 & 20.03 & 6.51 & 70.88 \\
income & $1990 / 1$ & 4.05 & 29.72 & 33.77 & 17.41 & 1.32 & 19.30 & 7.18 & 78.99 \\
countriesa & $2000 / 1$ & 9.20 & 48.44 & 57.64 & 22.85 & 1.74 & 23.42 & 10.71 & 116.36 \\
Developing & $1980 / 1$ & 3.91 & 27.89 & 31.80 & 16.74 & 1.21 & 21.45 & 7.14 & 78.34 \\
countries & $1990 / 1$ & 4.85 & 32.25 & 37.10 & 18.59 & 1.39 & 20.52 & 7.92 & 85.51 \\
& $2000 / 1$ & 10.70 & 52.92 & 63.63 & 24.86 & 1.80 & 25.41 & 12.49 & 128.18 \\
EU-15 & $1980 / 1$ & 7.20 & 22.89 & 30.09 & 53.82 & 0.24 & 15.44 & 5.55 & 105.15 \\
& $1990 / 1$ & 7.66 & 33.76 & 41.42 & 116.81 & 0.28 & 9.99 & 9.42 & 177.92 \\
Japan & $2000 / 1$ & 9.65 & 37.81 & 47.46 & 131.33 & 0.15 & 9.57 & 9.38 & 197.89 \\
& $1980 / 1$ & 1.13 & 6.64 & 7.77 & 1.22 & - & 9.20 & 2.56 & 20.74 \\
& $1990 / 1$ & 1.85 & 14.61 & 16.47 & 3.78 & - & 14.65 & 4.32 & 39.23 \\
NAFTA & $2000 / 1$ & 2.52 & 19.21 & 21.73 & 4.83 & - & 17.61 & 5.11 & 49.28 \\
& $1980 / 1$ & 2.62 & 11.67 & 14.30 & 4.42 & 0.37 & 8.86 & 2.78 & 30.73 \\
Other & $1990 / 1$ & 2.06 & 15.02 & 17.08 & 7.96 & 0.42 & 15.52 & 3.54 & 44.53 \\
industrial & $1900 / 1$ & 3.72 & 21.95 & 25.67 & 12.60 & 0.54 & 34.80 & 4.77 & 78.38 \\
countries & $1990 / 1$ & 0.47 & 1.68 & 2.14 & 3.79 & 0.06 & 1.53 & 0.62 & 8.15 \\
Total & $2000 / 1$ & 0.54 & 2.31 & 2.71 & 7.01 & 0.07 & 1.66 & 1.09 & 12.54 \\
exports & $1980 / 1$ & 15.33 & 70.74 & 86.10 & 79.99 & 1.89 & 56.48 & 18.64 & 243.10 \\
& $1990 / 1$ & 16.81 & 97.95 & 114.77 & 154.16 & 2.15 & 62.35 & 26.29 & 359.72 \\
\hline Source & $2000 / 1$ & 27.14 & 135.13 & 162.27 & 180.84 & 2.57 & 89.55 & 33.45 & 468.67 \\
\hline
\end{tabular}

Source: Aksoy (2005)

The development of RTAs is relevant to the problem of invasive species for three different reasons. The first is that many cover much broader issues than trade alone. An increasing number of RTAs address environmental issues. This is partly due to the limited scope for addressing environmental concerns in the General Agreement on Tariffs and Trade (GATT), but it is also in recognition of the fact that specific trade links involve specific environmental risks. The GATT does allow for actions in restraint of trade where human animal or plant life and health are threatened by trade. The Sanitary and Phytosanitary Agreement (SPA) provides the rules under which countries can do this, but allows individual countries some latitude. It encourages adoption of the standards set by the Codex Alimentarius Commission for food safety, the International Office of Epizootics for animal health, and the International Plant 
Protection Convention for plant health, but allows countries to choose their own level of protection (Jaffee and Henson, 2005).

There is little doubt that this has been and continues to be used as a trade protection device. Large numbers of countries are ineligible to supply certain markets with a range of animal products and food crops because of restrictions based on threats to plant and animal health (Sumner 2003). A review of the complaints lodged by developing countries over the use of the SPA reveals a persistent set of concerns, including the overly restrictive and non-scientifically based measures by high income countries for dealing with foot and mouth disease and bovine spongiform encephalopathy, and plant pests and pathogens, especially in the horticultural sector (Jaffee and Henson, 2005). Nor is the SPA the only instrument used to restrict trade. Bacterial wilt (Ralstonia solanacearum) is listed in US law as a potential biological weapon. When it was found on a shipment of pelargonium cuttings, for example, it resulted in quarantine restrictions that have severely affected the horticultural trade in Kenya (Rangi, 2004).

A second reason why South-South RTAs are relevant to the problem of invasive species is precisely because they open up new trading opportunities between developing countries. What makes this interesting from the perspective of IAS is that the development of South-South trade brings about closer linkages between ecosystems in which bioclimatic conditions are broadly similar, and therefore in which the risk that introduced species will establish, naturalise and spread is high. This aspect of the problem has not yet been investigated in the literature, but it is potentially an important risk factor. ${ }^{3}$ There is evidence from NAFTA that the agreement has facilitated the spread of species within the NAFTA area that were introduced to a NAFTA country from some other country (Perrault et al, 2003). The promotion of agricultural trade between bioclimatically matching regions in which resources for the detection and control of potentially invasive species are weak must be a concern.

A third reason is that cooperation within RTAs may be an important part of the solution to biological invasion externalities and the free rider problems attaching to the control of non-indigenous species. Schiff and Winters (2002) argue that if there are economies of scale or transboundary externalities, there is relatively little scope for market solutions to environmental problems, and regional cooperation can provide the answer. A number of RTAs include environmental agreements. In many cases, these are designed to force compliance with environmental laws. So, for example, the North American Free Trade Association (NAFTA) has a Commission for Environmental Cooperation. Its role is to ensure that member states do not seek a trade benefit or attract inward investment by failing to comply with environmental laws. The U.S.-Singapore Free Trade Agreement includes and environmental chapter

\footnotetext{
${ }^{3}$ The ratio between interception shares and import shares in any country gives a simple guide to the relative introduction risks attaching to different exporters. There are no data on this for developing countries, but a review of interception and trade data for the UK between 1996 and 2004 indicates the following ratios: Europe 0.85; Asia 4.25; Africa 0.91; North America 1.11; South America 1.29; Oceania 0.33 . The riskiest source of imports was Asia, accounting for $17 \%$ of all interceptions, but only $4 \%$ of trade. The least risky was Oceania, accounting for $9 \%$ of trade but only $3 \%$ of interceptions.
} 
requiring that both countries effectively enforce their environmental laws, and including fines for non-compliance (World Bank, 2005).

The same thing exists in developing country RTAs. The Southern Common Market (MERCOSUR), for example, includes an environmental working group charged with eliminating the use of environmental barriers to trade, promoting 'upward harmonization' of environmental management systems and securing cooperation on shared ecosystems. Indeed, many of the main South-South RTAs - MERCOSUR, the Andean Pact, the Common Market for Eastern and Southern Africa (COMESA), the Southern African Development Community (SADC), the ASEAN Free Trade Area (AFTA) and the Caribbean Community (CARICOM) - include agreements on standards (World Bank, 2005).

The regional scale is the appropriate level at which to manage environmental resources wherever the ecosystems affected are regional in extent. In marine systems, for example, the conservation of straddling or migratory stocks requires cooperation across the sea areas within which those stocks move. The conservation of such stocks is a regional public good, and subsidiarity indicates that the right level of governance is the regional level. Similarly, the control of the introduction of potentially invasive species within a trading group should be regulated at the level of that group. Not only does this make it possible to ensure that the resources committed to control are commensurate with the collective benefits it offers, it also minimises transaction costs by reducing the number of participants to those with a real stake in the public good, and builds trust by allowing repeated interaction between members over time (Sandler, 2005).

\section{Estimates of the damage costs of invasive species}

The first estimate of the costs of invasive species by the Office of Technology Assessment of the US Congress (1993), considered the ecological and economic effects of harmful invasive species within the US. It concluded that in the period from 1906, 59\% of all species introduced to the US had caused economic or ecological damage, and that the 79 most harmful had caused damage of $\$ 97$ billion over that period. Since then a number of papers by Pimentel and colleagues (Pimentel et al, 2000, 2001, 2005) have sought to update the OTA estimates and to extend them beyond the US. The second of the Pimentel papers included estimates for three developed and three developing countries - South Africa, India and Brazil. To date this remains the most comprehensive summary of the control costs and lost output associated with invasive species in agriculture, forestry and fisheries in 'poor' countries.

The findings of Pimentel et al (2001) are summarised in tables 7 and 8. They represent a simple sum of various dollar estimates of annual damage costs in the countries concerned made over the preceding decade. Because of the way in which they were acquired, the numbers cannot be taken as a good approximation of net costs of species introductions in any of the countries concerned. There are no estimates of any benefits that may have accrued from the activities that led to the introduction of invasive species. The estimates of damage costs in the background literature are not made in any coherent way and are extremely patchy. The findings are also inconsistent with the ecological literature in important respects - such as in the 
estimate of the proportion of introduced species that are 'harmful'. Nonetheless, it is interesting to consider the relative severity of the estimates in rich and poor countries.

Taking agricultural GDP in 1999 as the numeraire, the estimates reported in table 7 indicate that invasive species caused damage costs equal to $53 \%$ of agricultural GDP in the USA, 31\% in the UK and 48\% in Australia. By contrast damage costs in South Africa, India and Brazil were, respectively, 96\%, 78\% and 112\% of agricultural GDP. Of course there is considerable uncertainty about the Pimentel estimates given the ad hoc estimation methods. Public expenditure on invasive species control is not known in most countries, but where there are data it turns out to be very small relative to the Pimentel estimates. In the USA, for example, federal expenditure on invasive species in 1999 was less than USD 0.5b, i.e. $0.5 \%$ of the estimated damage costs in agriculture. While there almost certainly insufficient expenditure to counter the impact of invasive species, this also raises questions about the damage estimates themselves.

Table 7 Economic losses to introduced pests in crops, pastures, and forests in the United States, United Kingdom, Australia, South Africa, India, and Brazil (billion dollars per year)

\begin{tabular}{llllllll}
\hline Introduced pest & $\begin{array}{l}\text { United } \\
\text { States }\end{array}$ & $\begin{array}{l}\text { United } \\
\text { Kingdom }\end{array}$ & Australia & $\begin{array}{l}\text { South } \\
\text { Africa }\end{array}$ & India & Brazil & Total \\
\hline $\begin{array}{l}\text { Weeds } \\
\text { Crops }\end{array}$ & 27.9 & 1.4 & 1.8 & 1.5 & 37.8 & $17.0 \mathrm{a}$ & 87.4 \\
$\begin{array}{c}\text { Pastures } \\
\text { Vertebrates }\end{array}$ & 6.0 & - & 0.6 & - & 0.92 & - & 7.52 \\
$\quad \begin{array}{l}\text { Crops } \\
\text { Arthropods }\end{array}$ & $1.0 \mathrm{~b}$ & $1.2 \mathrm{c}$ & $0.2 \mathrm{~d}$ & $-\mathrm{e}$ & - & - & 2.4 \\
$\quad \begin{array}{ll}\text { Crops } \\
\text { Forests }\end{array}$ & 15.9 & 0.96 & 0.94 & 1.0 & 16.8 & 8.5 & 44.1 \\
$\begin{array}{l}\text { Plant } \\
\text { pathogens }\end{array}$ & 2.1 & - & - & - & - & - & 2.1 \\
$\quad \begin{array}{l}\text { Crops } \\
\text { Forests }\end{array}$ & 23.5 & 2.0 & & & & & \\
Total & 2.1 & - & 2.7 & 1.8 & 35.5 & 17.1 & 82.6 \\
\hline
\end{tabular}

a Pasture losses included in crop losses.

b Losses due to English starlings and English sparrows (Pimentel et al., 2000).

c Calculated damage losses from the European rabbit.

d Emmerson and McCulloch, 1994.

Source: Pimentel et al (2001)

Nevertheless, if the relative values were of the right order of magnitude, the impact of invasive species on agriculture is significantly greater in developing than in developed countries. Furthermore, since agriculture accounts for a higher share of GDP in developing countries, the impact of invasive species on overall economic performance is proportionately even greater in developing countries. In India, for example, Pimentel's estimates imply that annual invasive species control and damage costs were $20 \%$ of GDP in 1999, compared to less than 1\% in the USA. Pimentel's 2005 update of the US estimates added an estimate of the cost of weeds in lawns (without attempting to isolate non-indigenous from indigenous weeds, or to separate weed control and fertilization), but otherwise reports similar figures (Pimentel et al, 2005). 
There are a large number of case studies of the effects of particular invasive species, many of which focus on the USA (for a summary see Stutzman et al, 2004). Examples of invasive plants in the USA for which there exist cost estimates are leafy spurge (Bangsund et al, 1999), tansy ragwort (Coombs et al, 1996), yellow starthistle (Jetter et al, 2003) and tamarisk (Zavaleta 2000). A number of case studies of aquatic species have also been carried out, of which the impact of the zebra mussel, Dreissena polymorpha, on power stations is the best known (O'Neil, 1997), but others include the effect of the green crab, Carcinus maenas, on the North Pacific Ocean fisheries (Cohen et al., 1995). Internationally, there have also been assessments of the role of the comb jelly, Mnemiopsis leidii in changing the cost of fishing effort in the Black Sea (Knowler and Barbier, 2000; Knowler, 2005).

Table 8 Environmental losses to introduced pests in the United States, United Kingdom, Australia, South Africa, India, and Brazil (billion dollars per year)a

\begin{tabular}{llllllll}
\hline $\begin{array}{l}\text { Introduced } \\
\text { pest }\end{array}$ & $\begin{array}{l}\text { United } \\
\text { States }\end{array}$ & $\begin{array}{l}\text { United } \\
\text { Kingdom }\end{array}$ & Australia & $\begin{array}{l}\text { South } \\
\text { Africa }\end{array}$ & India & Brazil & Total \\
\hline $\begin{array}{l}\text { Plants } \\
\text { Mammals }\end{array}$ & 0.148 & - & - & 0.095 & - & - & 0.178 \\
$\quad$ & & & & & & & \\
$\quad$ Rats & 19.000 & 4.100 & 1.200 & 2.700 & 25.000 & 4.400 & 56.400 \\
$\quad$ Other & 18.106 & 1.200 & 4.655 & - & - & - & 23.961 \\
Birds & 1.100 & 0.270 & - & - & - & - & 1.370 \\
Reptiles/Amph. & 0.006 & - & - & - & - & - & 0.006 \\
Fishes & 1.000 & - & - & - & - & - & 1.000 \\
Arthropods & 2.137 & - & 0.228 & - & - & - & 2.365 \\
Mollusks & 1.305 & - & - & - & - & - & 1.305 \\
Livestock Diseases & 9.000 & - & 0.249 & 0.100 & - & - & 9.349 \\
Human Diseases & 6.500 & 1.000 & 0.534 & 0.118 & - & 2.333 & 10.467 \\
Total & 58.299 & 6.570 & 6.866 & 3.013 & 25.000 & 6.733 & 106.481 \\
\hline
\end{tabular}

Source: Pimentel et al (2001)

There are few case studies of individual invasive species in developing countries. Human diseases aside, invasive species that have the most direct effects on the livelihoods of the poor are those that impact agriculture, forestry and fisheries. The dominant crops grown in the poorer regions of the world are rice, maize, cassava, sorghum and millet. All are affected by invasives species - whether pests or pathogens. The range of effects includes the following:

- interference with crop growth through competition for light, water and nutrients

- allelopathy, or the production of toxins that inhibit the growth of other plants

- contamination of harvested crops

- provision of vectors for pests, pathogens, nemotodes, and insects

- interference with harvesting

- requirement for additional cleaning and processing

All of these have direct economic implications. Some increase the cost of production. Others reduce the value of harvested crops or result in their exclusion from international markets. The position is very similar with respect to animal pests and pathogens, foot and mouth disease being a good example. 
Although there are no very good estimates of the impact of invasive species on yields in poorer country, Oerke et al (1994) suggested that they may be around 50\%. Examples of pests and pathogens that have had particularly severe effects on crop yields in the World's poorest region, Sub-Saharan Africa, include witchweed (Striga hermonthica), grey leaf spot (Circosporda zeae-maydis), the large grain borer (Prostephanus truncatus), cassava mealybug (Phenacoccus manihoti) and the cassava green mite (Mononychellus tanajoa) (Rangi, 2004). Some of these species have been present for many decades. Others are new arrivals. The larger grain borer was apparently introduced from south and central America during the 1970s. It was first detected in Tanzania in the late 1970s and is now established in east, central, south and west Africa. It primarily affects grain in storage, causing losses of up to $30 \%$ within six months. Farrell and Schulten (2002) estimated that the income forgone as a result was in the order of USD90million for Tanzania alone.

The emergence of new agricultural pests has spurred the development of both new pesticides and alternative control measures, including biological control agents. For example, the cassava mealybug has been targeted by the parasitic wasp (Epidinocarsis lopezi), the cassava green mite by the mite (Typhodromalus aripo) and the large grain borer by the beetle Teretrisoma negrescens (Rangi, 2004). Such biocontrol agents are themselves introduced species, with potential ecological consequences in addition to the control they exercise over the invasive pest.

There are far fewer studies of the impacts of invasive species on particular systems. Exceptions include the African Lakes and the South African Fynbos. Kasulo (2000) analysed the ecological and socio-economic impact of invasive species in African lakes focusing on introduced fish species and water weeds-the Nile perch (Lates niloticus), the Tanganyika sardine (Limnothrissa miodon) and water hyacinth (Eichhornia crassipes) into Lakes Victoria, Kyoga, Nabugabo, Kariba, Kivu, Itezhitezhi and Malawi. While the introduction of Nile perch had a major impact on the structure and profitability of fisheries, it is believed to have caused the extinction of numerous endemic species. The introduction of the Tanganyika sardine also benefited fisheries but had less dramatic impacts on the ecosystems of the lakes to which it was introduced. The water hyacinth, on the other hand, has proliferated in most African lakes. It has obstructed water passages and displaced native aquatic plants, fish and invertebrates by cutting out light and depleting dissolved oxygen. The weed is also believed to harbor disease-carrying organisms, and has little potential for economic utilization. Kasulo's (2000) estimate of the annual cost of the hyacinth in terms of its impact on fisheries in this group of lakes was USD71.4.

The South African fynbos is affected by a number of invasive pinus, hakea and acacia species. By 2000 two thirds of the fynbos area in the Western Cape had been significantly impacted. Damage costs include a reduction in biodiversity and, in particular, of species important for the international flower trade. But they also include a change in ecosystem functioning and hydrology. A number of studies have hown that fynbos mountain catchments are extremely valuable in terms of their water yield, and that the value of changes in water yields exceeded expected restoration costs (Higgins et al., 1997; van Wilgen et al, 1996; van Wilgen et al, 1997; Turpie and Heydenrych, 2000; le Maitre et al, 2002). The result was a major control programme, the Working for Water Campaign, which had both restoration and poverty-alleviation goals. By 2004, the programme had cost in the region of USD400 million, and 
questions were being raised about its value relative to other development programmes. While the benefits of the programme in terms of employment and poverty alleviation are reasonably clear - the programme employed some 24000 people in 2000 - the environmental benefits aside from water flows are less easy to identify.

Turpie (2004) correctly points out that appropriate valuation of these benefits is needed to test the relative efficiency of conservation and development projects. Evaluation of the net benefits of resources committed to conservation and development projects includes a range of direct and indirect costs and benefits. It is easier to do in the case of control programmes for existing invasive species than it is for programmes designed to prevent the introduction of new potentially invasive species. In fact, the benefit-cost ratio of successful control programmes for particularly harmful invaders can be surprisingly high (Hill and Greathead, 2000), but this is like calculating the benefit-cost ratio of the purchase of a winning lottery ticket. The ex ante calculation involves uncertainty about the invasiveness of the species, the invasibility of the system being protected, the effectiveness of the control programme, and the responses of those whose life and livelihoods are affected by invasive species and their control.

To calculate the net benefit of restoration, control or eradication measures requires an evaluation not just of the damage or forgone output costs of invasive species and the cost of control, but also of the benefits conferred by the invader or the activities that support the introduction or spread of the invader, and the distribution of those benefits. Most case studies of invasive species involve estimates of damage and control costs and do not deal with the benefits of the actions that lead to either the introduction, establishment or spread of invasive species. When those benefits are taken into account it is not always obvious that eradication or control is the optimal strategy. For example, siam weed (Chromoleana odorata) was introduced into Ghana in the 1960s and by the end of century had spread to approximately $60 \%$ of the land area. It has had major ecological effects. Nevertheless, a survey of users found that few would support its eradication since it confers significant benefits in terms of fuel, fibres, building materials and medicinal products (Rangi, 2004). In semi-arid areas mesquite (Prosopis juliflora) is a similar case. In South Africa, it has invaded the semi-arid Nama and succulent karoo biomes, and once again has had major ecological effects. In the more arid regions, however, it is highly valued for its capacity to provide a more reliable source of fuel and fibre than many native species in dry conditions (GISP, 2004).

In many cases, control is exercised without explicit consideration of either damage costs or the benefits of the activities leading to the introduction, establishment or spread of invasive species. Certain pathogens, such as foot and mouth disease, are automatically eradicated whenever they appear without any benefit-cost calculation being made. In these circumstances it is still useful to consider the cost effectiveness of control options. The literature on cost effectiveness to date reflects a consensus that eradication is more cost-effective than control in most cases. There is no consensus on the relative cost effectiveness of eradication and prevention (through detection and interception in support of or red/black lists, or through quarantine). 
The conclusion that many have drawn is that all conservation and development projects are location-specific, that the interactions between local people and ecological resources matter, and that it is important to understand the distribution of the costs and benefits of environmental change (Grimble and Laidlaw, 2002). If the people in locations where potentially invasive species appear are poor, their capacity to deal with the problem will be low. Borggaard et al (2003), for example, note that cogon grass (Imperata cylindrica) has invaded shifting cultivation plots in many South and South East Asian countries. Since shifting cultivators are amongst the poorest members of those societies, the control measures needed to eradicate it (Johnson and Shilling, 2003) are beyond their means. The problem is exaggerated by the migration or displacement of shifting cultivators since new farmers may be unaware of local conditions, and so may not appreciate the extent of the problem (Adger et al, 2002). In these circumstances, it has been argued that the only effective strategies may be to manage for system resilience by adopting policies that enhance soil fertility, reduce clearing costs and increase the rate of forest recovery (Albers et al, 2005).

\section{Invasion externalities: economic instruments of IAS control in poor countries}

From an economic perspective, the problem of invasive species represents a classic market failure. Market prices of potentially invasive species do not reflect the costs they may impose on society, in part because many markets have been prevented from operating efficiently by agricultural policies and institutions. Agricultural tax/subsidy and price policies have increased the vulnerability of agroecosystems by reducing agro-biodiversity, and by encouraging farm management regimes that leave agroecosystems open to invasion. Moreover, the lack of well-defined property rights in land and ecological services has discouraged people from taking action to control invading species. At the same time, the deregulation of both national and international markets has reduced both the surveillance of trade and the barriers to trade (Perrings et al, 2002).

A second point made by Perrings et al (2002) is that there is a strong 'public good' element in the control of biological invasions. The benefits of quarantine, for example, are neither 'rival' nor 'exclusive'. If one extra person benefits from the protection offered by a quarantine policy it affects neither the cost of quarantine nor the benefits of quarantine to others. But because public goods are non-exclusive, any one person or any one country has a strong incentive to free-ride on the efforts of others. The implication of this is that if it were left to the market, there would be insufficient control of potentially invasive pests and pathogens. More importantly, the international control of many invasive species, such as infectious and communicable diseases, depends on the least effective provider - the weakest link in the chain (Sandler, 1997). If control of an invasive species involves containment (or eradication) by all landowners, it will only be as good as the containment (or eradication) activities of the least effective landowner.

Since biodiversity conservation is at once a global, regional, national and local public good, it requires programmes of public investment that operate over a wide range of spatial and temporal scales (Perrings and Gadgil, 2003). Moreover, a condition for an internationally efficient allocation of resources to conservation is that countries should be compensated for their contribution to the international public good. The 
incremental cost principle of the GEF implies just this, as does the CBD principle of the equitable sharing of the benefits of biodiversity conservation. Yet the structure of international markets and the rules governing international trade and investment mean that in practice those whose actions confer biodiversity benefits on others are seldom compensated. Equally, those whose actions impose biodiversity costs on others are seldom penalised.

It is not therefore surprising that the discussion has been dominated by instruments aimed at addressing the problems of externality and public goods. In the case of domestic markets, externalities can be addressed through a range of mechanisms extending from the assignment of property rights, through the use of market-based mechanisms such as taxes and subsidies, to simple regulatory measures supported by penalties for non-compliance. In international markets, where there is no sovereign authority, these options are not available. The choice of mechanisms open to any one country is limited by the bilateral and multilateral trade agreements to which it is party (Perrings et al, 2005). Much of the recent research on the economic problem of invasive species has accordingly focused on the options open to governments in these circumstances.

Table 9 Economic sanitary and phytosanitary instruments

National Instruments International Instruments

\begin{tabular}{ll}
\hline Eradication/control charges & Risk-related tariffs \\
Monitoring charges & Inspection fees \\
Biodiversity maintenance fees & Fines/non-compliance penalties \\
Environmental bonds & Tradable risk permits
\end{tabular}

Risk-related land use taxes

Fines/non-compliance penalties

'Green box' agricultural support measures

At a theoretical level, one of the main foci of this research has been the impact of tariffs, which concentrates on the interception of introduced species. Costello and MacAusland (2003) consider the relationship between trade, tariffs and invasive agricultural pests. They show that the impact depends on the domestic agricultural price elasticity of imports. An increase in the tariffs always reduces the volume of trade and hence the rate of introductions, but the resulting stimulation of domestic agriculture increases the vulnerability of the sector to invasions.

McAusland and Costello (2004) then consider the degree to which non-tariff instruments, specificially inspections, may be used in combination with tariffs to achieve efficient control over alien species introductions. They show that the optimal mix of tariffs and inspections depends both on the rate to which imports are 'infected' by alien species and on the expected damage due to introductions that are not intercepted. Where the expected damage of unintercepted introductions is high, inspections dominate tariffs. But where the infection rate is high, tariffs dominate inspections.

More recently, Margolis et al (2005) have applied the Grossman and Helpman (1994) model of tariff formation to the problem of international invasion externalities. They 
show that countries setting tariffs freely will indeed include expected damage cost of invasions into tariffs, but also that interest groups may set tariffs sub-optimally in order to introduce disguised protectionism.

Another novel instrument considered in the theoretical literature is tradable invasion risk permits. Horan and Lupi (2005) consider the introduction aquatic invasive species in the Great Lakes, and propose the use of tradable invasion risk permits to allocate resources efficiently between risk-reducing options. Using the example of a small class of potentially invasive species from the Ponto-Caspian region, they show that the approach may offer efficiency gains over the more conventional regulations over ballast water exchange.

In practice, the instruments available to national governments are those admitted under the General Agreement on Tariffs and Trade, the Sanitary and Phytosanitary Agreement, the International Plant Protection Convention and related agreements (Shine et al, 2005). The scope for using tariffs as a primary mechanism is strictly limited, and the only trade-related instruments involve defensive measures such as inspection and interception at ports of entry in support of black and white (or red, green and amber) lists, and combined with quarantine, confiscation and destruction.

There are few studies of the biodiversity impacts of economic measures permitted under current trade agreements. The Secretariat of the Convention of Biological Diversity has reviewed the effect of the Uruguay Round and its Agreement on Agriculture (URAA) on agrobiodiversity (SCBD, 2005). It concludes that the reduction of 'Amber Box' (trade distorting) measures under the URAA may have had positive effects on agrobiodiversity in countries where agriculture is highly intensive, but may have had negative effects in countries where agriculture is largely extensive and relies on traditional techniques. Moreover this is particularly likely to have been the case in marginal lands of importance to biodiversity. The elimination of agricultural support schemes in these cases merely increases the rate at which soil nutrients are mined, and reduces the resources committed to weed and pest control.

More interesting are the 'Green Box' (non-trade distorting) measures designed to internalise externalities or to initiate payments for agricultural services. Many of these are re-designed agriculture support measures. They have largely been used by developed countries, and in many cases appear to have been beneficial for agrobiodiversity. But the SCBD (2005) also notes that these have the potential to benefit biodiversity in developing countries where connected to wildlife or habitat conservation, or to the protection of traditional livestock strains and landraces. The report does not consider the problem of invasive species explicitly, but it would be consistent with this to suggest that Green Box agricultural support mechanisms that targeted invasion risks may be helpful in countries where agriculture is based on traditional landraces or livestock strains, and on production methods that are vulnerable to the effects of invasive weeds, pests and pathogens.

The principle behind Green Box measures is that the (national) beneficiaries of environmental services provided by farmers should pay for these services. This implies either payments to farmers when their management practices confer benefits on society, or taxes when their management practices impose costs on society. In some cases this may imply the allocation of property rights. If invasive species 
increase the risks of fire, for example, the allocation of rights can create a market in fire risks. Where property rights are ill-defined, it may be easier to tax activities that lead to IAS risks. The problem then becomes one of determining the appropriate level of taxes. While the problem is straightforward in theory - the appropriate tax is equal to the marginal external damage cost of the activity - in practice this may be hard to calculate. Taxes are set at levels that lead to the desired behaviour. This means that they depend on the elasticity of producer responses. Since response elasticities are typically sensitive to income, poverty becomes an issue in designing economic sanitary and phytosanitary instruments. Short run supply and demand elasticities can be extremely low amongst the poor (and even negative in the case of 'inferior' goods that provide essential life support). The relevant elasticities need to be understood and factored into the development of economic sanitary and phytosanitary instruments.

\section{Public investment in invasive species control in low-income countries}

The second element in the economic treatment of IAS is investment in IAS control (where this means detection, interception, eradication and control). International investment in the IAS problem is dominated by coordinated actions in response to particular threats such as SARS or aids, or to bilateral or multilateral conservation and development projects that include and element of invasive species control. The best known of these is the South African Working for Water project, of which the control of IAS in the fynbos is a part. In general, however, lending for invasive species control is a very small share of World Bank lending for environmental and natural resource management (ENRM) projects. Overall ENRM lending has fallen substantially in the last decade, both in absolute terms and as a percentage of total lending. In 2002 it was less than a third of what it had been in 1994. Since then it has been improving, but is still only around 40 per cent of 1994 levels (Acharya et al, 2004).

Identifying the invasive species element in ENRM and linking this to the problem of poverty is not easy. The connection between poverty and public investments in invasive species control is most readily obtained by considering investment strategies in poor regions (e.g. Sub-Saharan Africa). One problem is that invasive species are seldom explicitly identified. For example, a review of IDA, IBRD and GEF projects with a biodiversity element in the 1990s reported the Cape Peninsula biodiversity conservation project, but did not identify IAS as an element of that. Indeed, the only explicit reference to IAS was to a project for the eradication of IAS in Mauritius (MacKinnon e al, 2000). Invasive species are, however, a major component of the action plan of the environment initiative of the New Partnership for Africa's Development (NEPAD) (UNEP, 2003).

The action plan notes that the impacts of invasive species are 'a major public policy' concern in many countries of Africa, affecting water supplies, fisheries, forestry, horticulture, trade and tourism. It also notes that they are a primary cause of biodiversity loss and ecosystem decline, that they exacerbate poverty and threaten the sustainability of development strategies (UNEP, 2004).

The goal of the Programme Area on Prevention, Control and Management of Invasive Alien Species is stated to be "to minimise the impact of IAS on the African continent's people, economies and ecological systems. It proposes to use of the same 
regional groupings referred to earlier - the East African Community, the Southern Africa Development Community and the Common Market for Eastern and Southern Africa - to regulate and control the introduction and spread of potentially invasive alien species, exploiting mechanisms identified at the $6^{\text {th }}$ Conference of the Parties to the CBD. These include improvement in the capacity to undertake risk assessments, awareness raising and information provision, development of the institutional capacity to manage IAS (UNEP, 2004).

Table 10 GEF biodiversity projects to 2000

\begin{tabular}{|c|c|c|c|c|c|}
\hline Country & Project & Funder & $\begin{array}{r}\text { Project } \\
\text { r cost \$m }\end{array}$ & $\begin{array}{l}\text { Bio- } \\
\text { diversity } \\
\text { cost \$m }\end{array}$ & $\begin{array}{l}\text { Bank bio- } \\
\text { diversity } \\
\text { cost } \$ \mathrm{~m}\end{array}$ \\
\hline Algeria & Pilot Forestry and Watershed Management (1992) & IBRD & 37.4 & 0.4 & 0.27 \\
\hline Argentina & Biodiversity Conservation (1998) & GEF & 21.9 & 21.9 & 10.4 \\
\hline Argentina & Native Forests and Protected Areas & IB RD & 30 & 30 & 19.5 \\
\hline Benin & National Parks and Management (2000) & IDA & 24.2 & 24.2 & 6.8 \\
\hline Benin & Management of Natural Resources (1992) & IDA & 24.4 & 14.1 & 1.7 \\
\hline Brazil & National Environmental Project (1990) & IBRD & 166.4 & 166.4 & 117 \\
\hline Brazil & National Biodiversity Project and Fund (1996) & GEF & 45 & 45 & 30 \\
\hline Burkina Faso & Environmental Management (1991) & IDA & 25.2 & 3.8 & 2.48 \\
\hline $\begin{array}{l}\text { Burkina } \\
\text { d'Ivoire }\end{array}$ & $\begin{array}{l}\text { Faso/Côte Community-based Natural Resource and Wildlife } \\
\text { Management (1996) }\end{array}$ & GEF & 13.19 & 13.19 & 7 \\
\hline Cameroon & $\begin{array}{l}\text { Biodiversity Conservation and Management } \\
\text { (1995) }\end{array}$ & GEF & 12.39 & 12.39 & 5.96 \\
\hline Central & African & & & & \\
\hline Republic & Natural Resources Management (1990) & IDA & 26.2 & 3 & 2.18 \\
\hline Central & African Livestock Development and Rangeland & & & & \\
\hline Republic & Management (1995) & IDA & 32.45 & 0.3 & 0.15 \\
\hline Chad & Household Energy (1998) & IDA & 6.31 & 1.36 & 1.14 \\
\hline Chile & Environmental Institutions Development (1992) & IBRD & 32.8 & 16.4 & 5.75 \\
\hline China & Environmental Technical Assistance (1993) & IDA & 76 & 29.4 & 20 \\
\hline Côte d'Ivoire & Forestry Sector (1990) & IDA & 147.8 & 8.4 & 8.4 \\
\hline Côte d'Ivoire & $\begin{array}{l}\text { Rural Land Management and Community } \\
\text { Infrastructure Development (1997) } \\
\text { Monitoring System for the Galapagos Islands }\end{array}$ & IBRD & 71.5 & 1.64 & 0.94 \\
\hline Ecuador & (1999) & GEF & 1.59 & 1.59 & 0.94 \\
\hline Egypt & Matruh Resource Management (1993) & IDA & 29.5 & 1.7 & 1.27 \\
\hline Ghana & Natural Resource Management: Phase I & IDA & 23.6 & 9.3 & 22.7 \\
\hline Ghana & Natural Resource Management (1998) & GEF & 2.1 & 2.1 & 2.1 \\
\hline India & Maharashtra Forestry (1992) & IDA & 142 & 10.94 & 9.55 \\
\hline India & Madhya Pradesh Forestry (1995) & IDA & 67.3 & 19.05 & 16.27 \\
\hline India & Ecodevelopment (1997) & IDA & 47 & 47 & 28 \\
\hline India & Ecodevelopment (1997) & GEF & 20 & 20 & 20 \\
\hline Jordan & Second Tourism Development (1998) & IBRD & 44 & 9 & 6.55 \\
\hline Kenya & Protected Areas and Wildlife Services (1992) & IDA & 143 & 143 & 60 \\
\hline Kenya & Tana River National Primate Reserve (1997) & GEF & 7.14 & 7.14 & 6.2 \\
\hline
\end{tabular}

\section{Table 10 cont}

\begin{tabular}{|c|c|c|c|c|c|}
\hline Country & Project & Funde & $\begin{array}{l}\text { Project } \\
\text { cost \$m }\end{array}$ & $\begin{array}{l}\text { Bio- } \\
\text { diversity } \\
\text { cost \$m }\end{array}$ & $\begin{array}{l}\text { Bank bio- } \\
\text { diversity } \\
\text { cost } \$ \mathrm{~m}\end{array}$ \\
\hline $\begin{array}{l}\text { Kyrgyzstan, } \\
\text { Kazakhstan, } \\
\text { Uzbekistan }\end{array}$ & Central Asia Transboundary Biodiversity & GEF & 13.65 & 13.65 & 10.15 \\
\hline
\end{tabular}




\begin{tabular}{|c|c|c|c|c|c|}
\hline Madagascar & Environment Project I (1990) & IDA & 85.53 & 45.05 & 9.55 \\
\hline Madagascar & Second Environment Program (1997) & IDA & 134.2 & 56 & 12.52 \\
\hline Madagascar & Second Environment Program (1997) & GEF & 20.8 & 20.8 & 12.8 \\
\hline Malawi & Environmental support (1997) & IDA & 13.7 & 6.85 & 6.2 \\
\hline Mali & Natural Resource Management (1992) & IDA & 32.1 & 6.78 & 4.31 \\
\hline Mexico & Forestry Development (1992) & IBRD & 91.1 & 2.28 & 1.53 \\
\hline Mexico & Protected Areas Program (1992/1997) & GEF & 34.55 & 34.55 & 17.48 \\
\hline Mexico & Environmental Project (1992) & IBRD & 126.6 & 26.8 & 16.88 \\
\hline Mexico & Northern Border Environmental Project (1994) & IBRD & 762 & 15 & 7.24 \\
\hline Morocco & $\begin{array}{l}\text { Lakhdar Watershed Management Pilot Project } \\
\text { (1997) }\end{array}$ & IBRD & 5.8 & 0.83 & 0.57 \\
\hline Mozambique & $\begin{array}{l}\text { Transfrontier Conservation Areas Pilot and } \\
\text { Institutional Strengthening (1997) }\end{array}$ & GEF & 8.1 & 8.1 & 5 \\
\hline Nigeria & $\begin{array}{l}\text { Environmental Management (1992) } \\
\text { Environmental Protection and Resource }\end{array}$ & IDA & 37.9 & 3.3 & 2.18 \\
\hline Pakistan & Conservation (1992) & IDA & 57.2 & 6.4 & 3 \\
\hline Pakistan & Punjab Forest Sector Development (1995) & IDA & 33.75 & 0.67 & 0.58 \\
\hline Paraguay & $\begin{array}{l}\text { Natural Resources Management(1994) } \\
\text { Southern Africa Community Outreach } \\
\text { Programme for Conservation and Sustainable Use }\end{array}$ & IBRD & 79.1 & 14.83 & 9.38 \\
\hline Regional & $\begin{array}{l}\text { of Biological Resources } \\
\text { Sustainable and Participatory Energy }\end{array}$ & GEF & 0.92 & 0.75 & 0.75 \\
\hline Senegal & $\begin{array}{l}\text { Management (1997) } \\
\text { Sustainable and Participatory Energy }\end{array}$ & IDA & 19.9 & 5.2 & 4.7 \\
\hline Senegal & $\begin{array}{l}\text { Management (1997) } \\
\text { Conservation of Globally Significant Biodiversity } \\
\text { in Agricultural Landscapes through Conservation }\end{array}$ & GEF & 5.2 & 4.28 & 1.12 \\
\hline South Africa & $\begin{array}{l}\text { Farming (1999) } \\
\text { Sustainable Protected Area Development in }\end{array}$ & GEF & 1.72 & 0.75 & 1.63 \\
\hline South Africa & Namaqualand (2000) & GEF & 1 & 1 & 0.75 \\
\hline South Africa & Cape Peninsula Biodiversity (1998) & GEF & 91.2 & 91.2 & 12.3 \\
\hline Syria & $\begin{array}{l}\text { Conservation of Biodiversity and Protected Areas } \\
\text { Management (1999) } \\
\text { In-situ Conservation of Genetic Biodiversity }\end{array}$ & GEF & 1.43 & 0.75 & 0.75 \\
\hline Turkey & $\begin{array}{l}\text { (1993) } \\
\text { Institutional Capacity Building for Protected }\end{array}$ & GEF & 5.7 & 5.7 & 5.1 \\
\hline Uganda & $\begin{array}{l}\text { Areas Management and Sustainable Use (ICB- } \\
\text { PAMSU) (1998) } \\
\text { Institutional Capacity Building for Protected } \\
\text { Areas Management and Sustainable Use (ICB- }\end{array}$ & IDA & 18.29 & 14.72 & 9.96 \\
\hline Uganda & PAMSU) (1998) & GEF & 2 & 2 & 2 \\
\hline Venezuela & Inparques (1995) & IBRD & 95.9 & 82.2 & 47 \\
\hline Zambia & $\begin{array}{l}\text { Environmental Support Program (1997) } \\
\text { Savé Conservancy (IFC - Small and Medium }\end{array}$ & GEF & 20.8 & 10.4 & 6.4 \\
\hline Zimbabwe & $\begin{array}{l}\text { Enterprises, 1994) } \\
\text { Wildlife Management and Environmental }\end{array}$ & GEF & NA & NA & 1 \\
\hline Zimbabwe & Conservation (1998) & IDA & 70 & 70 & 62.5 \\
\hline Zimbabwe & Park Rehabilitation and Conservation (1998) & GEF & 5 & 5 & 5 \\
\hline
\end{tabular}

Source: MacKinnon et al (2000).

The foci for terrestrial systems under NEPAD are plant invaders in agriculture, forestry and rangelands in the Horn of Africa, sustainable management of invasive woody species in Southern Africa, and the control of the invasive Indian House Crow in Eastern Africa (UNEP, 2004). While this maps reasonably well into IAS project funding from the IBRD, IDA and GEF (see Table 9), it meshes less well with the priorities identified in Rangi (2003), for whom the primary concern remains the effect of IAS on agriculture. 
Part of the reason for this is may be that while IAS are a major threat to food security, and while food security is the highest priority for many African governments, the linkage between them has not hitherto been made (Rangi, 2003). Food security is certainly the first goal of poverty alleviation, which means that if IAS control is to be related to poverty alleviation the natural foci are indeed IAS that affect the supply of food and water. Since many of the world's poor live in marginal, highly disturbed lands that are often the first to be colonised by invasive species, and since they do indeed exploit these species for food, fuel and fibre, it is not surprising that they sometimes have an ambivalent attitude to IAS control. One implication may be that invasive species should not be controlled. Another may be that IAS control should not be undertaken unless other measures have been put in place to compensate the poor for the loss of resources that results.

\section{Factoring poverty into predictive modelling and management}

An important feature of biological invasions is that they are, ex ante, highly uncertain. Williamson (1999) argues that this is because there are no general laws governing invasions. If so, it follows that it is extremely difficult to model the process (Kareiva et al, 1996), and prediction of the population dynamics of a particular species in a particular habitat requires required detailed study of that species in that habitat (Lawton, 1999). Williamson (1999) claims that there were only two reasonably good predictors of the invasiveness of particular species: (a) a previous history of invasions by the same species, and (b) propagule pressure. Nevertheless, the assessment of the predictive capacity of models of the invasions process by the NAS Committee on the Scientific Basis for Predicting the Invasive Potential of Nonindigenous Plants and Plant Pests in the United States suggested that this may be too cautious, and that there are other 'biological leads' that can be followed to improve predictability of invasiveness (NAS, 2002). More importantly, these biological leads can be augmented by 'economic leads' - of which rural poverty is one.

Most recent work on the economics of IAS has involved the develop of models of decision-making under uncertainty, using a variant of variant of either optimal control or stochastic dynamic programming in a bio-economic or ecological economic framework (Eisworth and Johnson, 2002; Albers et al, 2005; Knowler and Barbier, 2005; Olson and Roy, 2002; Finnof et al, 2005; Perrings, 2005; Horan et al, 2002). The quality of the data in these models is taken as given, although it is recognised that the risks confronting decision-makers may not be independent of their actions.

The point has already been made that the nature and direction of pathways, the species that are likely to be introduced via those pathways, and the frequency of introductions (propagule pressure) are all dependent on trade (and aid) flows. Hence changes in the structure, volume and value of trade will affect the probability that species from particular regions will be introduced into other regions. As the NAS (2002) puts it, China is likely to become a source of new invasive plants in the USA simply because of the growth in bilateral trade between them, the fact that they share similar physical and climatic conditions and have many related plant species. Nevertheless, the only recommendations they make on steps to take to improve the predictive capacity of models of biological invasions involve biotic and abiotic variables. Climate matching models such as CLIMEX are recognised to be useful 
tools, and a range of research tasks are identified on, for example, host specificity amongst pathogens, the fate of biocontrol agents and the performance of US plants grown abroad. Nothing is said, however, about exploiting information on other factors that co-vary with biological invasions, such as trade or land-use, or with the resources that are committed to detection and interception, eradication and control.

Perrings et al (2002) make the point that the probability that a potentially invasive species is introduced, establishes and spreads depends on the strategy adopted to deal with invasive species. The main options are mitigation and adaptation. Mitigation is action to reducing the likelihood that a species will establish or spread. Adaptation is action that changes the cost of invasions, but does not affect the likelihood that they will occur. The choice between mitigation and adaptation strategies depends on their relative net benefits given the risk preferences of the decision-maker and the (Shogren, 2000; Shogren and Crocker, 1999; Leung et al, 2002), but it also depends crucially on the capacity to predict the consequences of current actions. If it is not possible to affect the likelihood of invasions, then the only possible strategy is adaptation (Perrings, 2005; Horan et al, 2002). The capacity to predict either invasiveness or invasibility allows decision-makers to opt for a strategy of mitigation, and this in turn changes the risk of invasions.

The likelihood of invasions depends on both the invasiveness of species and the invasibility of habiats. Both are influenced by socio-economic conditions. Invasiveness depends both on the properties of the organisms, resource flows (trade, transport and travel), and measures to detect and intercept introduced species. Invasibility depends on climatic and environmental conditions in the host system, but it also depends on the degree of habitat disturbance, fragmentation and simplification, on the openness of that system, and on the effectiveness of control measures. Once again, these are influenced by socio-economic conditions. At the macro level, the openness of a country's economy, the composition of its trade flows, its regulatory regimes and the importance of agriculture, forestry or tourism all make it more or less vulnerable to invasions by alien species. So islands are susceptible to invasions partly because their native biodiversity is vulnerable, but also because they are typically very open. Dalmazzone (2000) observed that the average percentage of merchandise imports as a share of the GDP is 43 percent for islands as against 27 percent for continental countries.

At the micro level the invasibility of a habitat depends on land use and land management, including the management of alien species. In other words, the risks of biological invasions are endogenous (Shogren, 2000; Finnoff et al, 2005). So the habitat disturbance associated with the migration of shifting cultivators into new lands in South-East Asia has been associated with the spread of cogon grass (Borggaard et al, 2003. Information of this kind may be used to improve the predictability of models. In the South African case, for example, models to predict the spread of IAS include at least some data on land use, but turn out to be quite sensitive to the modelling approach employed. Rouget et al (2003) found that between $27 \%$ and $32 \%$ of land untransformed by agriculture in the fynbos and the renosterveld might be expected to be invaded depending on whether rule-based or statistical modelling techniques are used. By adding models of the allocation of resources by resource users it should be possible to improve the capacity to predict changes in the invasibility of such habitats. Moreover, by adding models of trade and land use it 
should be possible to improve the capacity to predict both the introduction and spread of species. This, in turn, will make it possible to mitigate invasion risks. A strong positive correlation between trade volumes and the establishment of potentially invasive species has been shown for particular species of birds and fish, and there is some evidence of a correlation between the volume of all trade and general invasion risks (Dalmazzone, 2000; Vila and Pujadas, 2001; Levine and D'Antonio, 2003). Since poverty is positively correlated with many of the risk factors related both to the invasibility of ecosystems, and to the weakness of detection and control measures, it should prove possible to factor it into predictive models of biological invasions.

\section{References}

Acharya A., A. Aparatha-Hemantha and E. Tsutsui. 2004. The environment and natural resources management portfolio, The World Bank Group Environment Matters (June): 32-33.

Adger, W.N., P.M. Kelly, A. Winkels, Luong Quang Hai and C.Locke. 2002. Migration, remittances, livelihood trajectories and social resilience, Ambio 31: 358-366.

Aksoy, M.A. 2005. The evolution of agricultural trade flows, in M.A. Aksoy and J.C. Beghin, eds, Global Agricultural Trade and Developing Countries, World Bank, Washington, D.C.: 17-36.

Albers, H., M.J. Goldbach and D. Kaffine. 2005. Implications of agricultural policy for species invasion in shifting cultivation systems, Environment and Development Economics, in press.

Arrow, K.J., P. Dasgupta and K.-G. Mäler. 2003. Evaluating Projects and Assessing Sustainable Development in Imperfect Economies. Environmental and Resource Economics 26: 647-685.

Bangsund, D.A., F.L. Leistritz, and J.A. Leitch. 1999. Assessing Economic Impacts of Biological Control of Weeds: the Case of Leafy Spurge in Northern Great Plains of the United States. Journal of Environmental Management 56: 35-53.

Birdsall N. and J.L. Londono. 1997. Asset Inequality Matters: An Assessment of the World Bank's Approach to Poverty Reduction. American Economic Association Papers and Proceedings 87 (2): 32-37

Borggaard, O.K., A. Gafur and L. Peterson. 2003. Sustainability appraisal of shifting cultivation, Ambio 32: 118-123.

Chavas, J.-P. 2004 On Impatience, Economic Growth and the Environmental Kuznets Curve: A Dynamic Analysis of Resource Management, Environmental and Resource Economics 28: 123-152.

Cleaver, K.M. and A.G. Schreiber. 1994. Reversing the Spiral: The Population, Agriculture, and Environment Nexus in Sub-Saharan Africa, World Bank, Washington D.C.

Cohen A.N., J.T. Carlton, and M.C. Fountain 1995. Introduction, dispersal and potential impacts of the green crab Carcinus maenas in San Francisco Bay, California, Marine Biology 122(2): 225-237.

Cole M.A., Rayner A.J. and Bates J.M. 1997. The Environmental Kuznets Curve: an empirical analysis, Environment and Development Economics 2(4):

Coombs, E.M., H. Radtke, D.L. Isaacson, and S. Snyder. 1996.Economic and Regional Benefits from Biological Control of Tansy Ragwort, Senecio Jacobaea, in Oregon. In VC Moran and JH Hoffmann (eds.) International 
Symposium on Biological Control of Weeds. University of Cape Town. Stellenbosch: 489-494.

Costello, C. and C. McAusland. 2003. Protectionism, Trade and Measures of Damage from Exotic Species Introduction. American Journal of Agricultural Economics 85(4): 964- 975.

Dalmazzone, S. 2000. Economic Factors affecting vulnerability to biological invasions, in C. Perrings, M. Williamson and S. Dalmazzone (eds) The Economics of Biological Invasions, Cheltenham, Edward Elgar: 17-30.

Dasgupta P. 1993 An Inquiry into Well-being and Destitution, Oxford, Oxford University Press.

Dasgupta, P. 2001. Human Well-Being and the Natural Environment. Oxford: Oxford University Press.

De Janvry, A. and R. Garcia. 1988. Rural Poverty and Environmental degradation in Latin America: Causes, Effects and Alternative Solutions, S 88/1/L.3/Rev.2, IFAD, Rome.

Eisworth M.E. and W.S. Johnson, 2002. Managing Nonindigenous Invasive Species: Insights from Dynamic Analysis Environmental and Resource Economics 23: 319-342

Ekbom, A. and J. Boyo. 1999. Poverty and Environment: Evidence of Links and Integration into Country, Assistance Strategy Process, World Bank Discussion Paper No. 4, Environment Group, Africa Region, Washington D.C.

Enserink M. 1999. Biological invaders sweep in, Science 285: 1834-1836.

Evans, E.A. 2003. Economic dimensions of invasive species, Choices (June).

Evans, E.A., T.H. Spreen, and J.L. Knapp 2003. Economic Issues of Invasive Pests and Diseases and Food Safety, MGTC 02-2, University of Florida, International Agricultural Trade and Policy Center, Gainesville FA.

Farrell G. and G.M.M. Schulten. 202. Large grain borer in Africa: a history of efforts to limit its impact, Integrated Pest Management Review 7: 67-84.

Finnof D., J.F. Shogren, B. Leung and D. Lodge. 2005. The importance of bioeconomic feedback in invasive species management, Ecological Economics 52(3): 367-382.

Fisher, I. 1930. The Theory of Interest, Macmillan, New York.

Gelb A. and K. Hamilton. 2004.Taking resource dependence into account, Environment Matters: 26-27.

Global Invasive Species Program (GISP). 2004. Africa invaded: the growing danger of invasive alien species, GISP, Capetown.

Grossman, G.M. and E. Helpman. 1994. Protection for sale, American Economic Review 89(5): 1135-1155.

Grossman G.M. and A.B. Krueger. 1995. Economic Growth and the Environment, Quarterly Journal of Economics 110: 353-377.

Hamilton K. 2000. Sustaining Economic Welfare: Estimating Changes in Per Capita Wealth, Policy Research Working Paper 2498, The World Bank, Washington DC.

Hamilton K. and M. Clemens. 1999. Genuine savings rates in developing countries. World Bank Economic Review 13: 333-356.

Heath J. and H. Binswanger. 1996. Natural resource degradation effects of poverty and population growth are largely policy induce: the case of Colombia, Environment and Development Economics 1 (1): 65-84.

Higgins S.I., Azorin E.J., Cowling R.M. and Morris M.H. (1997). A dynamic ecological-economic model as a tool for conflict resolution in an invasive 
alien-plant, biological control and native-plant scenario. Ecological Economics 22: 141-154.

Hill G. and D. Greathead. 2000. Economic evaluation in classical biological control, in C. Perrings, M. Williamson and S. Dalmazzone (eds) The Economics of Biological Invasions, Cheltenham, Edward Elgar: 208-223.

Holden, Stein T., Bekele Shiferaw and M.Wik 1998. Poverty, market imperfections and time preferences: of relevance for environmental policy, Environment and Development Economics 3(1): 105-130.

Horan R.D., C. Perrings, F. Lupi and E. Bulte. 2002. Biological pollution prevention strategies under ignorance: the case of invasive species, American Journal of Agricultural Economics 84(5): 1303-1310.

Horan, R.D. and F. Lupi. 2005. Economic incentives for controlling trade-related biological invasions in the Great Lakes. Ecological Economics 52(3): 289304.

Jaffee S.M. and S. Henson. 2005. Agro-food exports from developing countries: the challenges posed by standards, in M.A. Aksoy and J.C. Beghin, eds, Global Agricultural Trade and Developing Countries, World Bank, Washington, D.C.: $91-114$.

Jazairy 1, Almagir M., and Panuccio T. 1992. The State of World Rural Poverty, IT Publications for IFAD, London.

Jetter, K.M., J.M. DiTomaso, D.J. Drake, K.M. Klonsky, M.J. Pitcairn, and D.A. Sumner. 2003. Biological Control of Yellow Starthistle. In D.A. Sumner (ed.). Exotic Pests and Diseases: Biology and Economics for Biosecurity Iowa State University Press. Ames, Iowa: 225-241.

Johnson, E.R.R.L. and D.G. Shilling, 2003. Cogon grass: Imperata cylindrical (L.) Palisot. Plant Conservation Alliance Alien Working Group, National Park Service, Washington DC.

Kairo M., B. Ali, O. Cheesman, K. Haysom and S. Murphy. 2003. Invasive Species Threats in the Caribbean Region, CABI, London.

Kasulo, V. 2000. The impact of invasive species in African lakes, in C. Perrings, M. Williamson and S. Dalmazzone (eds), The Economics of Biological Invasions. Cheltenham, Edward Elgar:183-207.

Knowler D. 2005. Reassessing the costs of biological invasion: Mnemiopsis leidyi in the Black Sea, Ecological Economics 52(2): 187-200.

Knowler D. and E.B. Barbier. 2000. The economics of an invading species: a theoretical model and case study application. in C. Perrings, M. Williamson and S. Dalmazzone (eds) The Economics of Biological Invasions, Cheltenham, Edward Elgar: 70-93.

Knowler, D. and E.B. Barbier. 2005. Importing exotic plants and the risk of invasion: are market based instruments adequate? Ecological Economics 52(3): 341354.

Kumar, S.K. and D. Hotchkiss. 1988. Consequences of Deforestation for Women's Time Allocation, Agricultural Production and Nutrition in the Hills of Nepal, Research Report No. 69, IFPRI, Washington D.C.

Lange G.-M. 2004. Wealth, natural capital, and sustainable development: contrasting examples from Botswana and Namibia, Environmental and Resource Economics 29: 257-283.

Kareiva P. 1996. Developing a predictive ecology for non-indigenous species and ecological invasions, Ecology 77: 1651-97.

Lawton J. 1999. Are there general laws in ecology?, Oikos 84: 177-92. 
Le Maitre D.C., B.W. van Wilgen, C.M. Gelderblom, C. Bailey, R.A. Chapman and J.A. Nel. 2002. Invasive alien trees and water resources in South Africa: case studies of the costs and benefits of management. Forest Ecology and Management 160: 143-159.

Leung, B., D.M. Lodge, D. Finnoff, J.F. Shogren, M.A. Lewis, and G. Lamberti. 2002. An ounce of prevention or a pound of cure: bioeconomic risk analysis of invasive species. Proceedings of the Royal Society of London, Biological Sciences 269(1508): 2407-2413.

Levine, J. and C. D’Antonio, 2003. Forecasting Biological Invasions with Increasing International Trade. Conservation Biology 17(1): 322-326.

Linde-Rahr, M. 2002. Household economics of agriculture and forestry in rural Vietnam, PhD Thesis, Department of Economics, University of Göteborg.

Lockwood J.L., P. Cassey and T. Blackburn. 2005. The role of propagule pressure in explaining species invasions, Trends in Ecology and Evolution 20(5): 223228.

Lopez, R. 1992. Environmental Degradation and Economic Openness in LDCs: The Poverty Linkage, American Journal of Agricultural Economics 74: 1138-45.

Lopez, R. and C. Scoseria. 1996. Environmental Sustainability and Poverty in Belize: A Policy Paper, Environment and Development Economics 1(3): 289-308.

Lovell S.J. and S. Stone. 2005. The economic impacts of aquatic invasive species: a review of the literature, Working Paper \# 05-02, U.S. Environmental Protection Agency National Center for Environmental Economics, Washington, D.C.

Margolis M., J. Shogren and C. Fischer. 2005. How trade politics affect invasive species control, Ecological Economics 52(3): 305-313.

Markandya, A. 2000. Poverty, Environment and Development, in A. Rose and L. Gabel, eds, Frontiers of Environmental Economics, Edward Elgar, Cheltenham: page numbers

Markandya, A. 2001. Poverty alleviation and sustainable development implications for the management of natural capital, World Bank, Washington D.C.

McAusland C. and C. Costello. 2004. Avoiding invasives: trade related policies for controlling unintentional exotic species introductions, Journal of Environmental Economics and Management 48, 954-977

MacKinnon K., N. Chow, E. Esikuri, and G. Platais, 2000. Conserving and Managing Biodiversity in Dryland Ecosystems, World Bank Environment Department Working Paper, World Bank, Washington D.C.

National Academy of Sciences (NAS) Committee on the Scientific Basis for Predicting the Invasive Potential of Nonindigenous Plants and Plant Pests in the United States. 2002. Predicting Invasions of Non-Indigenous Plants and Plant Pests, National Academy Press, Washington D.C.

Office of Technology Assessment. U.S. Congress (OTA). 1993. Harmful NonIndigenous Species in the United States. OTA Publication OTA-F-565. US Government Printing Office, Washington D.C.

Olson L. J. and S. Roy. 2002. The economics of controlling a stochastic biological invasion. American Journal of Agricultural Economics 84(5): 1311-1316.

O'Neill, C. 1997. Economic impact of Zebra Mussels: Results of the 1995 Zebra Mussel Information Clearinghouse Study. Great Lakes Res. Review 3(1): 3542.

Pender, J. L. 1996. Discount rates and credit markets: theory and evidence from rural India, Journal of Development Economics 50, 257-296. 
Perrault A., M. Bennett, S. Burgiel, A. Delach, and C. Muffett, 2003. Invasive Species, Agriculture and Trade: Case Studies form the NAFTA Context, North American Commission for Environmental Cooperation, Montreal.

Perrings C. 1989. An Optimal Path to Extinction: Poverty and Resource Degradation in the Open Agrarian Economy, Journal of Development Economics 30(1): 124.

Perrings C. 2005. Mitigation and adaptation strategies for the control of biological invasions, Ecological Economics 52 (3): 315-325

Perrings C., Dehnen-Schmutz K., Touza J. and Williamson M. 2005. How to manage biological invasions under globalization, Trends in Ecology and Evolution 20(5): 212-215.

Perrings C., M. Williamson and S. Dalmazzone (eds) 2000. The Economics of Biological Invasions, Edward Elgar, Cheltenham.

Perrings, C., M. Williamson, E. B. Barbier, D. Delfino, S. Dalmazzone, J. Shogren, P. Simmons, and A. Watkinson. 2002. Biological invasion risks and the public good: an economic perspective. Conservation Ecology 6(1): 1. [online] URL: http://www.consecol.org/vol6/iss1/art1

Perrings C. and Gadgil M. 2003 . Conserving biodiversity: reconciling local and global public benefits In Kaul I. , Conceicao P., le Goulven K. and Mendoza R.L. (eds) Providing global public goods: managing globalization, Oxford, OUP: 532-555.

Pimentel, D., L. Lach, R. Zuniga, and D. Morrison. 2000. Environmental and economic costs of nonindigenous species in the United States. Bioscience, 50(1): 53-56.

Pimentel, D., R. Zuniga, and D. Morrison. 2005. Update on the environmental and economic costs associated with alien-invasive species in the United States. Ecological Economics 52: 273-288.

Pimentel, David, S. McNair, S. Janecka, J. Wightman, C. Simmonds, C. O'Connell, E. Wong, L. Russel, J. Zern, T. Aquino and T. Tsomondo, 2001, Economic and environmental threats of alien plant, animal and microbe invasions, Agriculture, Ecosystems and Environment 84:1-20.

Pingali, P., Bigot, H and P. Binswanger. 1987. Agricultural mechanization and the evolution of farming systems in Sub-Saharan Africa, Johns Hopkins, Baltimore.

Polasky, S., C. Costello and C. McAusland. 2004. On trade, land- use and biodiversity. Journal of Environmental Economics and Management 48: 911925.

Rangi D.K. 2004. Invasive alien species: agriculture and development, Proceedings of a global synthesis workshop on biodiversity loss and species extinctions: managing risk in a changing world location?

Reed D. ed. 1996. Structural Adjustment, the Environment and Sustainable Development. Earthscan, London.

Rouget M., D.M. Richardson, R.M. Cowling, J.W. Lloyd and A.T. Lombard. 2003. Current patterns of habitat transformation and future threats to biodiversity in terrestrial ecosystems of the Cape Floristic Region, South Africa, Biological Conservation 112: 63-85

Sandler T. 2005. Regional public goods and regional cooperation, Background working paper for the Task Force on Global Public Goods, Stockholm, Sweden.

Sandler T. 1997. Global Challenges, Cambridge, Cambridge University Press. 
Schiff M., and L.A. Winters. 2003. Regional Integration and Development, World Bank, Washington, D.C.

Secretariat of the Convention on Biological Diversity (SCBD). 2005. The impact of trade liberalisation on agricultural biological diversity: domestic support measures and their effects on agricultural biological diversity, SCBD, Montreal.

Seldon T.M. and Song D. 1994. Environmental quality and development: is there a Kuznets curve for air pollution emissions? Journal of Environmental Economics and Management 27: 147-162.

Shafik N. 1994. Economic development and environmental quality: an econometric analysis, Oxford Economic Papers 46: 757-773.

Shine C., N. Williams and F Burhenne-Guilmin. 2005. Legal and institutional frameworks for invasive alien species, in Mooney, H.A., J. McNeely, L.E. Neville, P.J. Schei, J.K. Waage (eds). Invasive Alien Species: a new sysnthesis, Island Press, Washington, D.C.: 233-284.

Shogren, J.F. 2000. Risk Reduction Strategies against the 'explosive invader.' In C. Perrings, M. Williamson and S. Dalmazzone (eds) The Economics of Biological Invasions, Cheltenham, Edward Elgar: 56-69.

Shogren J. and Crocker T. 1999. Risk and its consequences, Journal of Environmental Economics and Management 37: 44-51.

Stern, D.I. 1998a. Progress on the Environmental Kuznets Curve, Environment and Development Economics 3: 381-394.

Stern, D.I. 1998b. The rise and fall of the Environmental Kuznets Curve, World Development 32(8): 1419-1439.

Stern, D.I. 2004.

Stern, D.I. and M.S. Common. 2001. Is there an Environmental Kuznets Curve for sulphur, Journal of Environmental Economics and Management 41: 162-178.

Stutzman, S. K. M. Jetter and K. M. Klonsky. 2004. An Annotated Bibliography on the Economics of Invasive Plants, University of California, Davis, Agricultural Issues Center.

Sumner D. A., ed. 2003. Exotic Pests and Diseases: Biology and Economics for Biosecurity, Iowa State Press, Ames, Iowa.

Tiffen M., M. Mortimore and F. Gichuki. 1994. More People, Less Erosion, Environmental Recovery in Kenya, John Wiley, New York.

Turpie J.K. 2004. The role of resource economics in the control of invasive alien plants in South Africa, South African Journal of Science 100(Jan/Feb): 87-93.

Turpie J.K. and B.J. Heydenrych. 2000. Economic consequences of alien infestation of the Cape Floral Kingdom's Fynbos vegetation. In C. Perrings, M. Williamson and S. Dalmazzone, eds, The Economics of Biological Invasions, Edward Elgar, Cheltenham: 152-182.

United Nations Environment Programme (UNEP). 2003. Action Plan of the Environment Initiative of the New Partnership for Africa's Development (NEPAD), UNEP, Nairobi.

Vila M. and J. Pujadas. 2001. Land use and socio-economic correlates of plant invasions in European and North African countries, Biological Conservation 100: 397-401.

van Wilgen B.W., P.R. Little, R.A. Chapman, A.H.M. Gorgens T. Willems and C. Marais. 1997. The sustainable development of water resources: history, financial costs and benefits of alien plant control programmes. South African Journal of Science 93: 404-411. 
van Wilgen B.W., R. Cowling and C.J. Mand Burgers. 1996. Valuation of ecosystem services: a case study from the fynbos, South Africa. BioScience 46: 184-189.

Ward J.M.J., E.L. Stromberg, D.C. Nowell and F.W. Nutter. 1999. Gray leaf spot: a disease of global importance in maize production, Plant disease 83: 884-895.

Williamson, M. 1996. Biological Invasions. Chapman and Hall, London.

World Bank, 2005. Global Economic Prospects, World Bank, Washington D.C..

World Commission on Environment and Development. 1987. Our Common Future, Oxford, Oxford University Press.

Zavaleta E. 2000. The Economic Value of Controlling an Invasive Shrub. Ambio 29(8): 462-467. 